\title{
De overtuigingsdader. Tussen overtuiging en psychopathologie
}

\author{
G. Glas*
}

De vraag die in deze bijdrage centraal staat luidt: vloeien delicten waarvan de verdachte zegt dat deze zijn gebaseerd op een religieuze overtuiging, voort uit psychopathologie of niet? Hoe dienen met andere woorden in het onderzoek naar de persoon van de verdachte die religieuze overtuigingen te worden geëvalueerd waarvan door verdachte of anderen wordt beweerd dat ze ten grondslag liggen aan het delict? In deze bijdrage zal ik de casus Mohammed B als voorbeeld nemen. Ik maak daarbij gebruik van documenten van de terechtzitting zoals die in de pers en op internet zijn verschenen. $\mathrm{Na}$ een eerste verkenning van de vragen die aan de orde kunnen komen, bespreek ik summier de psychopathologie van de waanvorming en ga ik in op de kentheorie van overtuigingen. In het laatste deel van mijn betoog kom ik terug op het fenomeen 'overtuigingsdader'.

\section{Waar gaat het over?}

Op 2 november 2004 werd Theo van Gogh, terwijl hij op zijn fiets door Amsterdam reed aangevallen door een jongeman in traditionele Marokkaanse kledij. De aanvaller loste enkele schoten en stak van Gogh vervolgens verschillende malen in de borst. Na een mislukte poging zich aan zijn aanvaller te onttrekken werd het slachtoffer - aan de overkant van de straat nogmaals enkele malen gestoken. Het mes liet de dader in de borst achter met daaraan geregen een verklaring behelzende een bedreiging met de dood gericht aan andere prominente Nederlanders en verwijzingen naar Joodse invloeden op de wereldpolitiek. Na zijn aanhouding werd in de kleding van de verdachte een tekst gevonden met in dichtvorm een radicaal islamitisch,

* Gerrit Glas is psychiater en bijzonder hoogleraar reformatorische wijsbegeerte aan de Universiteit Leiden en per 2006 hoogleraar wijsgerige aspecten van de psychiatrie. 
politiek-religieus credo. Uit dit politiek-religieuze credo sprak de verwachting dat de verdachte zijn daad niet zou overleven en dat hij door Allah daarvoor zou worden beloond. Uit het laatste woord van Mohammed B. tijdens de terechtzitting geef ik de volgende passages in citaat weer:

"Wat betreft de aanklacht van u, meneer de Officier van Justitie, daar kan ik mij helemaal mee vinden, in grote lijnen tenminste. Ik neem de volle verantwoordelijkheid op mij en u heeft gekenschetst dat wat mij eventueel zou hebben gedreven om te doen wat ik deed, dat dat puur uit mijn geloof is."

....."en ik ben niet hier om een politiek statement met een religieus tintje te geven, dat bespaar ik u, maar wat ik wel wil dat $\mathrm{u}$ wilt weten dat ik uit overtuiging heb gehandeld."

.... "ik heb gehandeld uit geloof en u hebt zelfs aangegeven: was het mijn vader geweest of mijn broertje dan had ik precies hetzelfde gedaan."

\section{Common-sense opvattingen}

Wie bij het publiek zijn oor te luisteren legt over de daden als die van Mohammed B. hoort vaak de reactie dat de persoon die een dergelijke daad pleegt wel 'gek' moet zijn. Deze reactie is voor ons betoog relevant omdat ze laat zien dat opvattingen over geestelijke (ab)normaliteit impliciet mede bepaald worden door ideeën over een gewenste morele orde. Men plaatst zich buiten die orde door religie als grond te noemen voor een moord.Vanuit een historisch perspectief is dit beroep op een morele orde als het gaat om de grens tussen wat geestelijk normaal en wat geestelijk abnormaal is, nogal betrekkelijk. Zo is er in de historie wel meer gedood met argumenten die in onze ogen niet deugen. Toch houden we de plegers van deze wandaden niet voor geestesziek. Denk bijvoorbeeld (het voorbeeld is wat afgezaagd) aan de kruistochten.

In het vervolg van de discussie komt dan nogal eens de tegenwerping dat wij toch in een beschaafdere tijd leven dan de Middeleeuwen waren en dat het daarom nu beter dan vroeger mogelijk is om de grens tussen 'sound' en 'unsoud minds' te trekken op basis van afwijkingen van de maatschappelijke norm. Men moet met andere woorden wel 'gek' zijn om van die beschaafde norm af te wijken. Ook deze tegenwerping schiet tekort. Ze laat zien dat het 
gedrag van de geesteszieke medemens impliciet door een morele bril wordt bekeken en wordt gezien als onbeschaafd of primitief. Geestesziekte is evenwel een realiteit die primair door andere dan morele krachten tot stand komt. Morele oordelen dienen te worden onderscheiden van het oordeel over ziek en niet-ziek. Dat er omstandigheden kunnen zijn dat 'mad' en 'bad' met elkaar verweven zijn, kan pas duidelijk worden op basis van een voorafgaand onderscheid tussen die twee.

Kijken we naar de relatie tussen overtuiging en daad dan is een derde veel gehoorde opmerking dat religieuze overtuigingen van mensen kunnen verschillen en dat wij mensen met die overtuigingen moeten respecteren ook al verschillen deze hemelsbreed van de onze. Tegelijk, zo zegt men, wordt de grens van wat tolerabel is overschreden als mensen naar hun overtuigingen gaan handelen en vervolgens een misdrijf plegen. De redenering is dus: een mentaal gezonde persoon is in staat het verschil te zien tussen iets vinden en iets doen en zou bijgevolg af moeten kunnen zien van religieus bepaalde handelingen als die handelingen hem of haar in strijd brengen met de wet of de algemeen geldende moraal. Dat niet doen zou een teken van mentale zwakte zijn. Ook deze manier van redeneren is evenwel niet geheel overtuigend. Ze leidt bovendien niet tot afbakening van ziekte en niet-ziekte. Voor de religieuze persoon geldt immers vaak dat de eigen (religieuze) overtuiging een hogere waarde heeft dan de publieke moraal of zelfs de wet. Ook levensovertuigingen waarvan de meeste mensen in onze cultuur vinden dat deze niet uitdrukking zijn van een mentale stoornis, zoals het Christendom, kennen de gedachte dat de eigen overtuiging soms boven de consensus dient te prevaleren. Men dient "Gode meer gehoorzaam te zijn dan mensen". Toch behandelen we hen die dit zeggen niet als geestesziek.

Een vierde, eveneens veel gehoorde benadering, luidt dat de verdachte die zich op religieuze overtuigingen beroept ter rechtvaardiging van zijn handelen, eigenlijk niets anders doet dan een rationalisatie geven voor wat in feite de uiting is van een psychologische zwakte. Met andere woorden: het gebeurde, het delict, is niet toe te schrijven aan religieuze gedrevenheid. Die gedrevenheid heeft zelf een psychologische achtergrond en wel in ervaringen van krenking, mislukking en/of onmacht. De verklaring van de verdachte is een mystificatie van wat er werkelijk aan de hand is: een scheefgroei in de ontwikkeling in de persoonlijkheid of een andere mentale stoornis. Hier tegenover moet worden gesteld dat religie niet in toto kan worden herleid tot psychopathologie. Er zijn mensen die uit zuiver religieuze motieven hande- 
len en er ook naderhand bij blijven niet anders gekund te hebben en die niet geestesziek zijn. Het religieuze is een categorie in zichzelf. Het kenmerkende van religies (althans sommige) is dat ze mensen er toe kan brengen om dingen te doen die buiten de normale orde liggen, zowel in positieve als in negatieve zin.

Laat ik in dit opzicht mijn kaarten maar op tafel leggen. Dat doe ik ook omdat het hier niet de plaats is om uitvoerig over de aard van religie te schrijven. Voor het vervolg van het betoog is evenwel van belang dat wanneer wordt gesproken over de relatie tussen overtuigingen en handelen, wordt uitgegaan van de volgende aannames ten aanzien van religie:

- Religieuze overtuigingen zijn niet altijd invoelbaar en worden ook niet altijd door alle omstanders voor rationeel gehouden.

- Religieuze overtuigingen hebben het in zich om tot handelingen te leiden; het zijn met andere woorden niet louter innerlijke toestanden; in de overtuiging zit een drang naar buiten, naar de sfeer van het handelen.

- Religieuze overtuigingen kunnen niet helemaal tot psychologische factoren worden herleid ook niet louter tot groepspsychologische fenomenen.

- Wel is de religieuze dimensie van het menselijk functioneren verweven met alle andere dimensies van het menselijk functioneren.

\section{Wanneer is een religieuze overtuiging een waan?}

Om op die vraag een antwoord te geven is het nodig eerst de definitie van de waan weer te geven zoals die in het meest gehanteerde handboek voor classificatie van psychiatrische stoornissen te vinden is, te weten de DSM - IV TR (APA 2000).

Een waan is:

"a false belief based on incorrect inference about external reality that is firmly sustained despite what almost everyone else believes and despite what constitutes incontrovertible and obvious proof or evidence to the contrary. The belief is not one ordinarily accepted by other members of the person's culture or subculture (e.g., it is not an article of religious faith). When a false belief involves a value judgment, it is regarded as a delusion only when the judgment is so extreme as to defy credibility. Delusional conviction occurs 
on a continuum and can sometimes be inferred from an individual's behavior. It is often difficult to distinguish between a delusion and an overvalued idea (in which case the individual has an unreasonable belief or idea but does not hold it as firmly as is the case with a delusion)." [cursief door GG]

Opgemerkt moet worden dat deze definitie is bedoeld voor gebruik in de psychiatrische praktijk. Ze is niet primair geformuleerd om de behoefte aan conceptuele scherpte van filosofen of juristen te bevredigen. Dat gezegd zijnde dient te worden erkend dat er tot de dag van vandaag een levendige discussie over het karakter van de waan in de psychiatrie bestaat. Kern van de definitie is de gedachte dat een waan een onjuiste overtuiging is die is gebaseerd op een onjuiste redenering over iets in de externe realiteit. Ter bepaling van de gedachten: de patiënt met een paranoïde waan ziet drie groene auto's kort na elkaar en meent dat hij wordt gevolgd door ambtenaren van de geheime dienst. Een ander belangrijk element in de definitie is dat de betreffende overtuiging niet deel moet uitmaken van het bestand van overtuigingen dat door de leden van een bepaalde cultuur of subcultuur wordt gedeeld. Ten slotte is opmerkelijk hoe voorzichtig de DSM is in het voor afwijkend verklaren van overtuigingen die een waardeoordeel omvatten: het moet gaan om extreme opvattingen die elke geloofwaardigheid missen (toch voelt men hier al aan, hoe lastig dit criterium te hanteren is in het geval van de politiek-religieuze Islam).

Er zijn zoals gezegd enkele problemen met deze definitie. Eén van deze problemen betreft het criterium van de incorrigeerbaarheid. Een waan is volgens de gangbare zienswijze een incorrigeerbare, onjuiste overtuiging. Deze incorrigeerbaarheid heeft evenwel een eigenaardig karakter. Het betekent niet dat de psychoticus elk realiteitsbesef mist. Vaak houdt de psychoticus aan de waan vast in het volle besef dat anderen de waan niet delen en een heel andere kijk op de werkelijkheid hebben. Veel psychotici weten heel goed dat hun overtuiging een privé-karakter heeft. Soms lijkt het dan ook of psychotici in twee werelden leven, de wereld van de waan en de gewone wereld gaat. De incorrigeerbaarheid gaat dus niet zo ver dat men in een soort 'autistische' wereld leeft. Dat blijkt ook uit het feit dat psychotici zich vaak pas naar hun waan gaan gedragen als deze een grote affectieve betekenis krijgt, bijvoorbeeld als deze gepaard gaat met een gevoel van angst, woede of onmacht. Pas dan wordt het rekening houden met anderen overschaduwd door de eigen preoccupaties. Een volgend punt betreft de vraag wat onder een onjuiste overtuiging dient te worden verstaan. Wat waar is (of juist) is in 
de praktijk niet altijd gemakkelijk te bepalen. Bovendien is die waarheid vaak ook nogal afhankelijk van de context. Vaak sluit de waan aan bij op zich juiste waarnemingen. Zelfs de interpretatie van die waarnemingen hoeft op zich niet onjuist of onmogelijk te zijn. De vrouw met een jaloersheidswaan kan ten aanzien van het gedrag van haar echtgenoot op zich juiste observaties hebben en beschikken over een verscherpt zintuig voor mogelijke ontrouw, een observatie die bij Freud al te vinden is. De vertekening van de realiteit berust dan niet in de overtuiging als zodanig als wel in de eenzijdigheid en de vertekening van de realiteit en in de hoeveelheid mentale ruimte die de overtuiging in beslag neemt.

Een derde punt betreft de vraag of het in de waan wel alleen om een verkeerde gedachte (overtuiging, 'belief') gaat. Deze vraag vloeit voort uit de observatie dat het waandenkbeeld vaak een affectieve achtergrond heeft. Vaak wordt de impact van een waan op het dagelijkse leven niet zozeer bepaald door de inhoud van de waan als zodanig, maar door de wijze waarop de waan aansluit bij de zorgen en verwachtingen van de betrokkene.

Het vierde en belangrijkste punt betreft de vraag of de wijze waarop wanen worden geconceptualiseerd niet teveel wordt bepaald door een verouderde, positivistisch getinte epistemologie. Het achterliggende model is dan dat de persoon kennis draagt van de werkelijkheid door zintuiglijke gewaarwordingen, die vervolgens worden geïnterpreteerd en tot een geheel worden geweven en die uiteindelijk leiden tot handelen en het innemen van een bepaalde houding. De waan wordt dan een soort cognitieve vergissing, een foutieve interpretatie of redenering bij een intacte perceptie. Ze zou in feite het gevolg zijn van het tekortschieten van het vermogen om interne representaties van de werkelijkheid (met name gedachten) te toetsen aan de werkelijkheid. In filosofische vaktaal staat deze kentheorie bekend als evidentialistisch. Hier zal ik straks nog verder op ingaan.

Eerst staan we evenwel nog kort stil bij de manier waarop in de psychiatrie gepoogd is meer greep te krijgen op de enorme verscheidenheid in de waanvorming. In het kader van ons betoog is vooral het onderscheid tussen primaire wanen en waanachtige ideeën van belang. Volgens psychopathologen als Jaspers, Kretschmer en Scharfeter zouden primaire wanen de betrokkene overvallen. In de meest typerende gevallen zou het gaan om een onbegrijpelijke en nieuwe vorm van betekenis verlenen. Deze vorm van betekenisverlening zou direct zijn, dat wil zeggen niet gebaseerd zijn op voorafgaande redenering. Bovendien zou de waan een 'intrusief' (letterlijk: zich opdrin- 
gend; binnendringend) karakter dragen, ze breekt met andere woorden van buitenaf in. Bij Jaspers is het achterliggende denkschema Kantiaans. Zintuiglijke gewaarwordingen zouden op zich ongestoord worden gewekt, maar er zou een fout optreden bij de categorisatie van die gewaarwordingen. Waanachtige ideeën, daarentegen, zouden een vooral affectieve basis hebben en optreden bij gevoelens van schuld, angst, jaloezie en dergelijke. Dat zou die ideeën ook een veel begrijpelijker karakter geven. Voor het maken van een onderscheid tussen religieuze overtuigingen en religieuze wanen helpt het bovengenoemde onderscheid evenwel niet. Religieuze overtuigingen kunnen iemand overvallen en ze kunnen ook een sterk affectieve basis hebben. Het is niet zo dat als een religieuze overtuiging iemand overvalt dit een aanwijzing voor psychopathologie is, net zo min als het feit dat een religieuze overtuiging langzaam op een meer affectieve basis ontstaat een aanwijzing is voor het ontbreken van psychopathologie.

Jackson en Fulford (1997), die een nauwkeurige beschrijving en analyse geven van een aantal patiënten die waren gediagnosticeerd als lijdende aan een religieuze waan, komen tot de conclusie dat geen van de volgende criteria onderscheidend is tussen een waan en een religieuze overtuiging:

- incorrigeerbaarheid;

- niet geaccepteerd worden door de subcultuur van de betrokkene

- gebrek aan inzicht

- $\quad$ het bizarre karakter van de inhoud

- duur van de overtuiging

- onvrijwilligheid van de overtuiging en

- verslechtering van functioneren.

Op de achtergrond speelt hier een discussie over het psychiatrische ziektebegrip (zie Fulford 2000). Zo keert Fulford zich tegen een opvatting van ziekte die is gebaseerd op het werk van Jerome Wakefield (Wakefield 1992), die meent dat het mogelijk is om ziekten waarde-neutraal te definiëren. Wakefields definitie van ziekte als 'harmful disfunction' bouwt voort evolutionaire benaderingen van het functiebegrip. Om precies te zijn: de disfunctie kan volgens Wakefield waarde-neutraal worden gedefinieerd, namelijk in termen van evolutionair nadeel; de schade ('harm') kan betrekking hebben op bestaansdomeinen waar menselijke waarden een rol spelen, waarden die op hun beurt niet primair evolutionair hoeven te worden verklaard. Fulford stelt daar tegenover dat ook het begrip disfunctie in het geval van de mens altijd een waardecomponent heeft. De stoornis in de functie is met andere woorden 
pas een stoornis in licht van het geheel van het menselijk functioneren. Ten aanzien van de waardering van religieuze overtuigingen betekent dit dat het totaal van het bestaan van de betreffende persoon in ogenschouw moet worden genomen. Ziekte is volgens Fulford 'failure of action' in plaats van 'failure of function'. Deze 'failure of action' dient dan, volgens hem, te worden gedefinieerd als een vorm van inconsistentie die er ofwel toe leidt dat de betreffende overtuiging er maar een beetje bij bungelt, ofwel dat hij het leven van betrokkene doet desintegreren. We zouden dit ook nog anders kunnen zeggen: of een overtuiging leidt tot een 'failure of action' wordt niet zozeer door die overtuiging als zodanig bepaald, maar vooral door de manier waarop de betrokkene ermee omgaat en deze overtuiging een plaats geeft in zijn leven. Mogelijk dat Jackson en Fulford iets te ver gaan in hun kritiek op de gebruikelijke criteria voor de afgrenzing tussen wanen en alledaagse overtuigingen (zie bijv. ook Jones 1999). Toch is hun benadering waardevol omdat deze recht doet aan de normatieve aspecten van de diagnostiek van de waan; en daarmee van de discussie over de grens tussen normaliteit en psychopathologie.

We willen daarom nog wat dieper op deze benadering ingaan. Ik neem daarbij mijn uitgangspunt in de godsdienstfilosofie. Want het is in de godsdienstfilosofie dat uitvoerig is gezocht naar criteria voor de rechtvaardiging van religieuze overtuigingen. Mij is geen enkele beschouwing over de theorie van de waanvorming bekend waarin dit spoor wordt bewandeld. Wij zullen ons dus zelf een weg door het conceptuele woud dienen te banen.

\section{Epistemologie van religieuze overtuigingen}

Wanneer is een overtuiging gerechtvaardigd? Met die vraag hebben godsdienstfilosofen zich door de eeuwen heen uitvoerig bezig gehouden. Ik wil om te beginnen twee extreme posities schetsen in het debat over de gerechtvaardigdheid van overtuigingen (zie ook Feivett \& Sweetman, 1992; hoofdstuk 1).

De eerste positie is evidentialistisch en stelt dat kennis, c.q. het hebben van een overtuiging, berust op 'justified true belief'. De benadering is kenmerkend voor de filosofie van Locke en Hume. Een overtuiging is waar als deze gerechtvaardigd kan worden. Het bestand van ware kennis bestaat enerzijds uit basiskennis, die ofwel zelf-evident is, ofwel incorrigeerbaar, ofwel recht- 
streeks voortspruit uit de zintuigen. Anderzijds bestaat deze kennis uit kennis die uit deze basiskennis met behulp van de logica kan worden afgeleid. Zelfevident is die kennis die tautologisch is. Incorrigeerbaar is de kennis die door niemand kan worden bevestigd of weerlegd en die zich onweerstaanbaar aan de betrokkene opdringt. Een voorbeeld hiervan is de ervaring van pijn. Religieuze overtuigingen vallen in de regel niet onder deze categorie omdat een kenmerk van deze overtuigingen is dat zij gedeeld plegen te worden (let wel we hebben het hier over overtuigingen en niet over waarnemingen, die natuurlijk wel vaak een privé-karakter hebben). Direct zintuiglijke kennis is die kennis die louter en alleen op waarneming berust. De rechtvaardiging van kennis bestaat nu hieruit, dat van een bepaalde kennisinhoud wordt nagegaan of deze òfwel behoort tot het bestand van de basiskennis òfwel behoort tot die kennis die uit deze basis kan worden afgeleid. Het zogenaamde positivisme in de wetenschapsleer is een voorbeeld van een evidentialistische kennisleer toegepast op wetenschappelijke kennis.

Het probleem van het evidentialisme is dat ondanks de schijn van duidelijkheid er toch een zekere willekeur optreedt bij het toepassen van de criteria voor rechtvaardiging van kennis. Anders gezegd, het is simpelweg ondoenlijk om van alle kennis waarover wij menen te beschikken, na te gaan of deze aan de criteria voor rechtvaardiging van kennis voldoet. Er is zeer veel kennis waar wij zonder een spoor van twijfel op vertrouwen en waarvan strikt genomen zou moeten worden nagegaan of deze aan de criteria voor rechtvaardiging voldoet. Dat geldt voor de wet van de zwaartekracht, het opgaan van de zon en mijn herinnering van het feit dat ik deze dag ben begonnen met het eten van twee boterhammen. In de praktijk passen wij evenwel een strenge selectie toe als het gaat om het hanteren van de criteria voor rechtvaardiging van kennis. Als we al onze expliciete en impliciete kennis aan de juist genoemde kennistoets zouden moeten onderwerpen, zou het leven onleefbaar worden. Vanuit de kentheorie gezien berust die selectie op willekeur: waarom zou geloof in een God wel steeds weer opnieuw moeten worden getoetst en waarom durven we met de wet van de zwaartekracht wel op de schouders van andere te staan? Een ander meer theoretisch bezwaar is dat het criterium voor rechtvaardiging van kennis zelf niet uit de criteria voor rechtvaardiging van kennis kan worden afgeleid. Het kenniscriterium is, met andere woorden, zelfreferentieel inconsistent; we zien dit criterium niet, we hebben er geen incorrigeerbare ervaring van en het is ook niet tautologisch. Evidentialistische benaderingen plegen uiterst kritisch te staan tegenover religieuze overtuigingen. Als contrast is het daarom goed om 
deze benadering te vergelijken met een radicaal tegenovergestelde, namelijk fideïstische opvatting van (geloofs)overtuigingen (zie hiervoor Plantinga \& Wolterstorff 1984). Volgens het fideïsme brengen geloofsovertuigingen hun eigen reden met zich mee. Het meest beroemd is in dit verband de formulering van Blaise Pascal die stelde dat "het hart zijn redenen heeft die de rede niet kent". Bij 'redenen van het hart' kan men denken aan een meer gevoelsmatige of esthetische of morele wijze van overtuigd raken. Bezwaren die tegen deze benadering zijn ingebracht luiden onder andere dat het nog maar de vraag is of geloofsovertuigingen hun grond louter in zichzelf hebben. Vaak speelt bijvoorbeeld de ervaring een belangrijke rol in het overtuigd raken. Die ervaring is niet altijd privé en vaak ook toetsbaar. En ook al valt een bepaalde overtuiging ons als het ware in de schoot, dan nog is het zo dat vaak in tweede instantie redenering en observatie mede een rol spelen in het consolideren van die overtuiging. Dit roept de vraag op of er misschien een derde weg is.

Volgens Alvin Plantinga (Amerikaans godsdienstfilosoof) is die weg er wanneer enerzijds wordt uitgegaan van overtuigingen die 'properly basic' zijn en wanneer er anderzijds ruimte blijft voor een bescheiden evidentialistische kritiek. Tot de overtuigingen die 'properly basic' zijn behoren die overtuigingen die zijn gebaseerd op directe zintuiglijke kennis, geheugenkennis, a priori kennis en kennis van 'other minds'. De prima facie rechtvaardiging van deze kennis ligt in onze neiging om automatisch geloof te hechten aan dit type overtuigingen. Deze overtuigingen hebben met andere woorden een 'felt attractivness', we zijn in normale situaties niet geneigd vragen te stellen bij deze vormen van kennis. Volgens Plantinga hoeft dit dus ook niet, tenzij er redenen zijn om dit wel te doen. Zo kan iemand beweren dat hij iets heeft gezien en behoeft deze bewering pas nader onderzoek als daar reden toe is, bijvoorbeeld als anderen zeggen iets anders te hebben gezien. De criteria voor 'proper basicality' zijn niet a priori vast te stellen. Ze worden inductief, dat wil zeggen van onderaf, vastgesteld. Van belang is voorts de context waarin overtuigingen tot stand komen. Zo geldt voor religieuze kennis dat deze pas geloofwaardig wordt in de relevante geloofscontext. Bovendien - en dit is voor Plantinga de tweede pijler voor zijn kentheorie - geldt voor overtuigingen dat zij alleen dan geloofwaardig zijn als ze worden geproduceerd door een goed functionerend ken-apparaat. Kennis ontstaat met andere woorden alleen dan als de cognitieve vermogens van iemand intact zijn. Plantinga meent dat elementaire geloofskennis aan de criteria van 'proper basicality' voldoet. Hij denkt daarbij aan uitspraken als: 
"God bestaat", "God heeft mij lief" of "ik ben klein en nietig tegenover God" (voor een volledige uitwerking Plantinga 2000).

Ik vat samen: we hebben gezien dat de evidentialistische benadering van de definitie van de waan faalt. Er is bij de waanvorming meer aan de hand dan een falend logisch of redenerend vermogen. Ik ben geneigd Alvin Plantinga te volgen in zijn opvatting dat sommige 'geloofs'overtuigingen properly basic zijn, dat willen zeggen voor waar mogen worden aangenomen door de betrokkene als ze een onmiddellijk karakter hebben (niet berusten of reflectie of inductief redeneren), als ze in de passende geloofscontext ontstaan en dat alles bij een intact werking van de cognitieve vermogens. Ik realiseer mij ondertussen dat Plantinga's kentheorie niet onomstreden is en veel discussie heeft opgeroepen. $\mathrm{Zij}$ doet evenwel recht aan het gegeven dat onze overtuigingen als het ware gegeven zijn en niet vragen om een nader onderzoek zolang aan de criteria van 'proper basicality' is voldaan. Ik laat dit punt rusten omdat in het geval van de overtuigingsdader wij niet zozeer met 'properly basic' religieuze overtuigingen zitten, maar met meer complexe overtuigen. Laten we eens kijken of ons uitstapje naar de godsdienstfilosofie ons helpt om zicht te krijgen op de overtuigingen van de overtuigingsdader. We zullen daarbij aannemen dat de cognitieve vermogens van de overtuigingsdader intact zijn.

\section{De overtuigingsdader}

'Properly basic' zou de overtuiging kunnen zijn: "ik ben door de profeet geroepen" of: "ik ben geroepen martelaar te worden". Bij de overtuigingsdader is er evenwel meer aan de hand, zo lijkt het. Er lijkt sprake te zijn van een complexe overtuiging, bijvoorbeeld in de vorm van "ik ben geroepen door de profeet en daarom moet ik X doden". Met andere woorden: de overtuigingsdader heeft een overtuiging (geroepen te zijn) en daarnaast nog een andere (of zelfs meta-) overtuiging, namelijk dat die roeping rechtvaardigt dat X wordt gedood; en wel door diegene die de eerste overtuiging heeft. Deze metaovertuiging leent zich echter wel, althans gedeeltelijk, voor een evidentialistische kritiek. Zo zou de betrokkene zich moeten afvragen: is deze metaovertuiging, namelijk $X$ te moeten doden, wel in overeenstemming met de overige geloofsleer? En hoe weet ik dat het $\mathrm{X}$ moet zijn en niet $\mathrm{Y}$ die gedood moet worden? Is de overtuiging $X$ te moeten doden wel in de passende geloofscontext geboren of is zij meer het resultaat van persoonlijke 
wraakgevoelens en gekwetstheid? En boven dit alles, is de verdachte wel in staat tot een dergelijk zelf onderzoek? Met de term zelfonderzoek maken we nieuwe stap in de discussie. Zelfonderzoek vraagt namelijk om inzicht. Het is met behulp van de term inzicht dat we iets preciezer kunnen worden in de afgrenzing van overtuiging en waan. Punt van overeenstemming tussen Jackson en Fulfords benadering enerzijds en die van Plantinga en mij anderzijds is dat onderzocht moet worden of de overtuiging op een vloeiende en vanzelfsprekende manier ingeweven is in het leven van de betrokkene. De term inzicht voegt evenwel nog een dimensie toe. Als ik het goed zie kunnen drie vormen van inzicht worden onderscheiden.

In de eerste plaats kan inzicht betrekking hebben op de aard van de overtuiging. We zouden hier kunnen spreken van inzicht 1 , of inzicht op het eerste niveau. Inzicht op dit niveau gaat over de vraag of de overtuiging waar of onwaar is, c.q. of ze rationeel of irrationeel is. Een tweede niveau van inzicht (inzicht 2) betreft het inzicht in de gevolgen van de overtuiging. Houdt de betrokkene ook rekening met de gevoelens van anderen? Houdt hij ook rekening met de context waarin hij zijn overtuigingen heeft gekregen en waarin hij deze overtuiging tot uitdrukking wil brengen? Inzicht op het derde niveau (inzicht 3) betreft een nog algemener niveau van inzicht, namelijk het gebalanceerd, flexibel en op verantwoorde wijze betrokken zijn op de omgeving en het vanuit dit betrokken zijn bepalen hoe men dient te handelen.

Ik realiseer mij dat, door het zo te zeggen, gemakkelijk de voorstelling kan ontstaan dat inzicht de religieuze overtuiging omvat en daarmee mogelijk ook neutraliseert. De ware gelovige zal hier niet in mee willen gaan en juist beweren dat het geloof het inzicht vormgeeft en richt. Ik moet het punt hier laten rusten, omdat het ons te ver zou voeren, namelijk naar de klassieke en eeuwenoude debatten over fides en ratio. Laat ik er hier - lapidair - het volgende over opmerken. Ik zie religieus geloof niet als synoniem met achterlijkheid of een vrijwillig beperken van de reikwijdte van de verstandelijke vermogens. Idealiter scherpt religieus geloof de verstandelijke vermogens. Voor dit betoog is het voldoende vast te stellen dat er altijd een wisselwerking is tussen geloof en inzicht en dat ware geloofsovertuigingen haaks staan op bepaalde vanzelfsprekendheden. Dit leidt tot nader onderzoek en verdieping én verfijning van inzicht en van overtuiging.

Toegepast op de casus Mohammed B. betekent het onderscheid tussen de drie vormen van inzicht naar mijn indruk het volgende. Op het niveau van 
inzicht 1 lijkt het mij onbeslisbaar of wij in het geval van Mohammed B. te maken hebben met een 'properly basic' overtuiging. Niet alleen zijn we niet geïnformeerd over zijn cognitieve vermogens; we weten ook niet op wat voor zintuiglijke indrukken of geheugenkennis hij zijn opvattingen baseert. Voor de beoordeling van het delict doet dat er echter ook niet zoveel toe omdat dit delict is gebaseerd op een complexe overtuiging waarin vooral inzicht 2 en inzicht 3 spelen. Ten aanzien van inzicht 2 is het opvallend dat Mohammed B. hier wel over lijkt te beschikken. Tijdens zijn slotbetoog richtte hij zich bijvoorbeeld tot de moeder van het slachtoffer, tot de Officier, tot de getuige-deskundige en ook tot de politieagenten. Hij is tot op belangrijke hoogte in staat om zich te verplaatsen in wat het delict voor hen heeft betekend. Ten aanzien van inzicht 3 kan mijns inziens gesproken worden van een gedeeltelijk ontbreken van inzicht. Er is sprake van een aanzienlijke blikvernauwing, waardoor enerzijds bij verdachte buiten beschouwing blijft hoe zijn biografie invloed heeft op zijn religieuze radicalisering en waarbij anderzijds buiten beeld blijft of deze daad de zaak van het Islamisme wel werkelijk dient. Is het ontbreken van inzicht 3 reden genoeg om te spreken van psychopathologie? Dat gaat mij te ver. Als er al sprake is van psychopathologie dan gaat het om een "psychopathologie van alledag", om met Freud te spreken. Met 'psychopathologie van alledag' bedoel ik hier dat het gaat om beperkingen die op grote schaal voorkomen en niet voorbehouden zijn aan de psychiatrische patiënt. Zeer veel mensen realiseren zich maar zeer gedeeltelijk wat hun gedragingen en/of opvattingen zouden betekenen wanneer zij maatgevend zouden zijn voor groepen van mensen of zelfs een hele natie.

\section{Pathologie van het verlangen}

We dienen nog één stap verder te zetten. Tot nu toe hebben wij vooral stilgestaan bij overtuigingen. Wij hebben geprobeerd enig zicht op overtuigingen te krijgen vanuit het perspectief van het inzicht. Overtuigingen zijn ook niet de enige bouwsteen die ten grondslag ligt aan het handelen. De filosofie kent in dit verband de leer van het praktische syllogisme dat stelt dat handelen is gebaseerd op de combinatie van verlangen (of de wens) en overtuiging. Verlangen plus overtuiging 'veroorzaakt' het handelen. Een vraag zou nu kunnen zijn of er ook een pathologie van het verlangen bestaat die ten grondslag ligt aan het delict. Een additionele vraag zou kunnen zijn in hoeverre er mogelijk iets pathologisch zit in de manier waarop het verlangen 
structurerend heeft gewerkt in het tot stand komen van de overtuiging. Verlangen zou in het geval van Mohammed B. kunnen betekenen: het verlangen naar een wereld die is gebaseerd op de Islam, of: een wereld waarin er geen ongelovigen meer bestaan. Of: het verlangen strijder voor de ware godsdienst te zijn en hier als uitverkorene een belangrijke rol in te spelen. Het syllogisme zou dan zo kunnen luiden: "Ik, Mohammed B., verlang een wereld van de zuivere Islam. Het beoogde slachtoffer staat de realisering van zo'n werkelijkheid in de weg. Ergo: het slachtoffer moet worden gedood".

Het gaat hier mij niet om de feitelijke correctheid van de invulling van de termen, maar om de gedachte er achter. De vraag zou kunnen luiden of er in de sfeer van het verlangen sprake is van pathologie. Ik kan mij hier door gebrek aan kennis over de biografie van Mohammed B. geen uitspraken over veroorloven. Het is duidelijk dat wij hier op een lastig terrein terechtkomen. Religieuze verlangens kunnen immers gevoed worden door persoonlijke frustraties. In theorie zou er een situatie kunnen bestaan waarin de vroege socialisatie van verdachte in combinatie met bepaalde frustrerende gebeurtenissen in zijn leven hebben geleid tot scheefgroei van de persoonlijkheid en dientengevolge tot scheefgroei van zijn verlangens. Bepaalde religieuze overtuigingen zouden vervolgens een soort wensvervullend karakter kunnen krijgen en tot het delict kunnen leiden. Nogmaals het gaat mij hier niet om de feitelijke juistheid van deze constructie maar om de vraag of deze redenering licht werpt op het fenomeen overtuigingsdader.

Ik meen dat deze gedachtegang ons in wezen niet veel verder helpt als het gaat om de relatie tussen overtuiging en daad. Want het is een van tweeën: ofwel het verlangen versterkt de overtuiging; ze geeft aan het verlangen meer kracht, maar niet noodzakelijk meer richting en focus; ofwel de overtuiging is de rationalisatie die het verlangen legitimeert en min of meer toevallig in een bepaalde richting kanaliseert. In het laatste geval tornt dit type van verklaren aan het genuïene karakter van de overtuiging. De overtuiging is dan slechts in schijn religieus en dient in wezen andere doelen. Een tussenvariant zou zijn de situatie waarin scheefgroei in de persoonlijkheidsstructuur en een daaruit voortvloeiende scheefgroei van de verlangens gepaard gaat met een authentiek geloof. In dit laatste geval zal mijns inziens moeten worden gewogen welke van de twee componenten het meeste gewicht in de schaal heeft gelegd in de totstandkoming van het delict. De vraag is dan: waarom moest het delict worden gepleegd? Vanwege de overtuiging of vanwege het scheefgegroeide verlangen? Ik realiseer mij dat het in de 
praktijk heel moeilijk kan zijn om op deze vraag een antwoord te geven. Maar van belang is dan dat waar de weegschaal doorslaat naar de overtuiging we het spoor kunnen volgen dat we bij de bespreking van de verschillende vormen van inzicht kozen; en dat waar de weegschaal doorslaat naar de kant van het verlangen er in wezen geen sprake meer is van een overtuigingsdader maar van een dader die een overtuiging opvoert als legitimatie van een verlangen waarin het in feite om heel andere doelen gaat (zelfbevestiging; ongedaan maken van krenking en dergelijke).

\section{Conclusie}

Indien bij de overtuigingsdader sprake is van psychopathologie dan dient die te worden gezocht in de sfeer van inzicht 3 . Het is evenwel de vraag of deze psychopathologie de grens naar de psychopathologie in engere zin overschrijdt. In vele gevallen zal dit niet het geval zijn. Het fenomeen van de overtuigingsdader blijft daarom enigmatisch. De overtuigingsdader toont ons iets van de diepte en aard van de religie. De religie heeft mensen tot bovenmenselijke prestatie aangezet. Maar zij heeft anderzijds ook een huiveringwekkende kant, zoals duidelijk wordt uit de laatste woorden van Mohammed B.:

"En u mag al uw psychologen, al uw psychiaters, al uw deskundigen op mij afsturen, maar ik zeg $\mathrm{u}, \mathrm{u}$ zult dat nooit begrijpen, $\mathrm{u}$ kunt het niet begrijpen en ik zeg $u$, als ik de mogelijkheid had, ik zou vrijkomen en ik had de mogelijkheid om het nóg een keer te doen wat ik op 2 november heb gedaan, dan zeg ik Wallah, ik zal het precies hetzelfde hebben gedaan." 


\section{Enige literatuur}

American Psychiatric Association (2000). Diagnostic and Statistical Manual of Mental Disorders. Fourth Edition. Text Revised. Washington DC: American Psychiatric Association.

Fulford, K.W.M. (2000). Teleology without tears: naturalism, neonaturalism, and evaluationism in the analysis of function statements in biology (and a bet on the twenty-first century). Philosophy, Psychiatry, Psychology, Vol. 7, 77-94.

Geivett, R.D. \& Sweetman, B. (Eds.), Contemporary perspectives on religious epistemology. Oxford: Oxford University Press, 1992.

Glas, G. (1999). Inzicht - tussen proces en ervaring. In: Handboek Integratieve Psychotherapie (red. S. Colijn, E.C.A. Collumbien, R.W. Trijsburg, G. Lietaer). Maarssen: Elsevier, 1999, HIP 3/29. I 3.2-1 - I 3.2 -24.

Jackson, M. \& K.W.M. Fulford (1997). Spiritual experience and psychopathology. Philosophy, Psychiatry, Psychology, Vol. 4, 41-65 (+ commentaren 66-90).

Jones, E. (1999). The phenomenology of abnormal belief: a philosophical and psychiatric inquiry. Philosophy, Psychiatry, Psychology, Vol. 6, 1-16 (+ commentaren pp. 18-28).

Plantinga, A. (2000). Warranted Christian Belief. Oxford: Oxford University Press, 2000.

Plantinga, A. \& Wolterstorff, N. (Eds.) (1984), Faith and Rationality. Reason and Belief in God. Notre Dame/London: University of Notre Dame Press.

Wakefield, J.C. (1992). Disorder as harmful dysfunction: a conceptual critique of DSM-III-R's definition of mental disorder. Psychological Review, Vol. 99, 232-247. 